\title{
Hastanede Yatan COVID-19 Tanılı Hastalarda Görülen Nörolojik Semptomlar ve Hastalık Şiddeti ile iliş̧kisi
}

\author{
Neurological Symptoms in Hospitalized Patients with COVID-19 Diagnosis and the \\ Relationship with Disease Severity
}

\section{Onur Serdar GENÇLER}

\author{
Yüksek Iihtisas Üniversitesi, Medical Park Ankara Batıkent Hastanesi, Nöroloji Anabilim Dalı, Ankara, Türkiye
}

Öz

Giriş: Koronavirüs hastalığı 2019 (COVID-19) tüm dünyada hızla yayılarak pandemiye neden oldu. Pandeminin başından bu yana hastalarda nörolojik bulgular da bildirilmeye başlandı. Son veriler, ağır akut solunum yolu yetersizliği sendromu korona virüs-2 (SARSCoV-2)'nin hem nörotropik hem de nörovirülan etkileri olduğunu göstermektedir. Bu çalışma, COVID-19 tanısı ile hastaneye yatırılan hastalarda nörolojik bulguların varlığı ile bu bulguların COVID-19 şiddeti ile ilişkisini değerlendirmeyi amaçlamıştır.

Materyal ve Metod: SARS-CoV-2 pozitif saptanan ve hastaneye yatış endikasyonu olan hastalar çalışmaya dahil edildi. Hastaların demografik özellikleri, sistemik semptomları, laboratuvar değerleri ve bilgisayarlı toraks tomografisi bulguları kayıt edildi. Hastaların nörolojik bulguları deneyimli bir nörolog tarafından değerlendirildi ve hastalık şiddeti ile ilişkisi analiz edildi.

Bulgular: Çalışmaya dahil edilen 66 hastanın (33 kadın, 33 erkek), yaş ortanca değeri 34,5 idi. Hastaların 33'ü (\%50) hafif, 28 'i (\%42.4) orta, 5'i (\%7.6) ağır şiddette COVID-19'a sahipti. En sık görülen semptom ateş yüksekliği idi (\%48.5). 43 hastada (\%65.2) en az bir nörolojik semptom saptandı. Disguzi (\%27.3), hipozmi-anozmi (\%27.3), baş ağrısı (\%25.8) ve kas ağrısı (\%24.2) en sık görülen nörolojik semptomlardı. Hafif COVID-19 hastaları arasında nörolojik semptomları olan bireylerin hastanede yatış süreleri nörolojik semptomları olmayan hastalara göre daha uzundu $(\mathrm{p}=0.017)$

Sonuç: $\mathrm{Bu}$ çalışmada COVID-19 hastalarının büyük bir kısmında nörolojik semptomlar gözlenmiştir. Ayrıca bu çalışma nörolojik belirtilerin, yalnızca COVID-19'lu, yaşlı, yoğun bakım hastalarında değil hafif şiddetli, genç COVID-19 hastalarında da oluşabileceğini ortaya koymuştur. $\mathrm{Bu}$ sebeple, bu hasta grubunda hastanede yatış süresi uzayabilir. Sonuç olarak COVID-19'un, şiddetine bakılmaksızın nörolojik rahatsızlıklar açısından potansiyel bir risk faktörü olabileceği hekimler tarafından akılda tutulmalıdır.

Anahtar Sözcükler: COVID-19, pandemi, nörolojik belirtiler, sinir sistemi invazyon
ABSTRACT

Introduction: Coronavirus disease 2019 (COVID-19) spread rapidly all over the world, causing a pandemic. Neurological findings have also been reported in patients since the beginning of the pandemic. Recent data suggest that severe acute respiratory syndrome coronavirus- 2 (SARS-CoV-2) has both neurotropic and neurovirulent effects. This study aimed to evaluate the presence of neurological findings in hospitalized patients with the diagnosis of COVID-19 and the relationship of these findings with the severity of COVID-19.

Material and Methods: Patients, positive for SARS-CoV-2 and had an indication of hospitalization were included in the study. Demographic characteristics, systemic symptoms, laboratory values and computed chest tomography findings of the patients were recorded. Neurological findings of the patients were evaluated by an experienced neurologist, and the relationship between these findings and the disease severity was analyzed.

Results: The median age of 66 patients ( 33 females, 33 males) included in the study was 34.5 . Of the patients, $33(50 \%)$ had mild, $28(42.4 \%)$ had moderate, 5 (7.6\%) had severe COVID-19. The most common symptom was fever $(48.5 \%)$. At least one neurologic symptom was detected in 43 patients $(65.2 \%)$. Dysgeusia ( $27.3 \%)$, hyposmia-anosmia $(27.3 \%)$, headache $(25.8 \%)$ and muscle pain $(24.2 \%)$ were the most common neurological symptoms. Among mild COVID-19 patients, individuals with neurological symptoms had longer hospitalization periods, than the patients without neurological symptoms $(\mathrm{p}=0.017)$.

Conclusion: Neurological symptoms were observed in the majority of patients with COVID-19 in this study. Besides this study revealed that neurological symptoms may occur not only in aged intensive care patients with COVID-19, but also in young patients, with mild COVID-19. Therefore the hospitalization period may be prolonged in this patient group. In conclusion, regardless of its severity, physicians should keep in mind that COVID-19 may be a potential risk factor for neurological disorders.

Keywords: COVID-19, pandemic, neurological symptoms, nervous system invasion 


\section{Giriș}

Aralık 2019 sonunda Çin'in Hubei eyaletinin Wuhan şehrinde sebebi bilinmeyen pnömoni vakalarının görülmeye başlandığı bildirildi (1). Pnömoni hızlı bir şekilde Çin'in diğer eyaletlerine de yayıldı ve çoğu vakanın Huanan deniz ürünleri pazarı ile teması olduğu tespit edildi (2). Hastalık kısa sürede tüm dünyaya yayılmaya başladı ve vaka sayısı hızla yükseldi. Etken ajanın yeni bir korona virüs olduğu teyit edildi (3). Dünya Sağlık Örgütü (DSÖ), 11 Şubat 2020'de ise bu yeni korona virüs pnömonisini, koronavirüs hastalığ 2019 (COVID-19) olarak isimlendirildi (4). Bu yeni korona virüs de "International Committee on Taxonomy of Viruses (ICTV)" tarafindan şiddetli akut solunum yolu sendromu koronavirüsü 2 (SARS-CoV-2) olarak adlandırıldı (3). 11 Mart 2020'de ise oluşan bu salgın DSÖ tarafindan pandemi ilan edildi (5).

COVID-19 genellikle hafif seyirlidir, bazen asemptomatik de olabilir. Ancak bazen çoklu organ yetmezliği ve akut respiratuar distress sendromu (ARDS) gelişebilmektedir (6). COVID-19'un en s1k görülen semptomları; ateş, öksürük ve yorgunluktur. Dispne, boğaz ağrısı, ishal ve baş ağrısı gibi çeşitli semptomlar da görülebilmektedir (7). Bilimsel çalışmalar koronavirüs enfeksiyonlarının her zaman solunum yollarına sınırlı kalmadığını, sinir sistemi ile diğer sistemlere de virüsün yayılabildiğini göstermektedir (8). Koronavirüsler de dahil olmak üzere çeşitli respiratuar virüsler nöroinvaziv ve nörotropik etkiye sahiptirler. Bu sayede nörolojik tutuluma sebep olabilmektedirler (9). COVID-19 pandemisi sırasındaki gözlemsel çalışmalarda SARS-CoV-2 hastalarının baş ağrısı, bulantı, kusma, miyalji, diziness, hipoguzi, hiposmi ve bilinç bozukluğu gibi semptomlarla başvurması, virüsün sinir sistemi tutulumu yapabileceğini düşündürtmektedir (10).

$\mathrm{Bu}$ çalışmada COVID-19 tanısı ile hastaneye yatırılan hastalardaki nörolojik semptom ve bulguların varlı̆̆ı ve sıklıkları ile bu bulguların COVID-19 şiddeti ile ilişkisinin araştırılması hedeflenmiştir.

\section{Materyal ve Metod}

\section{Çalışma Planı ve Popülasyonu}

Bu kesitsel çalışma Medicalpark Ankara Batıkent Hastanesi'nde 5 Nisan 2020 ile 15 Haziran 2020 tarihleri arasında, DSÖ geçici kılavuzuna (11) göre COVID-19 tanısı alan ve yatarak tedavi gören hastalarda gerçekleştirildi. COVID-19 tanısı, nazo-farengeal ve oro-farengeal sürüntülerinde gerçek zamanlı polimeraz zincir reaksiyonu (RT-PCR) testi ile SARS-CoV2'nin pozitif saptanması olarak tanımlandı (12). Çalışmaya dahil edilme kriterleri; çalışmaya katılmaya gönüllü olmak ve 18 yaşından büyük olmaktır. Çalışmadan dışlanma kriterleri; halihazırda hastada engelliliğe yol açan kronik nörolojik hastalık veya kronik başka bir sistemik hastalığın olmasıdır. Bu çalışma İyi Klinik Uygulama ilkelerine ve Helsinki Bildirgesi'ne uygun olarak düzenlenmiştir. Çalışma protokolü Yüksek İhtisas Üniversitesi Etik Kurulu tarafından onaylanmıştır. Çalışmaya başlamadan önce her katılımcıdan bilgilendirilmiş gönüllü onam formu alınmıştır.

\section{Veri Toplama}

Hastaların yaş, cinsiyet, sistemik semptomlar (ateş, öksürük, boğaz ağrıs1, göğüs ağrısı, solunum sıkıntısı, sırt-bel ağrıs1, halsizlik-yorgunluk, iştah kaybı, ishal, bulantı-kusma, karın ağrıs1, cilt döküntüsü), ko-mormid hastalıklar(HT, DM, koroner arter hastalığı, KOAH, astım, inme, kanser, bağışıklık sistem hastalıkları, tiroit hastalığı, KBY), alkol ve sigara kullanımı gibi demografik özellikleri sorgulandı ve kayıt edildi. Ayrıca detaylı laboratuvar testleri [tam kan sayımı, CRP, ALT, AST, LDH, üre, kreatin, kreatin kinaz, ferritin, D-dimer, D vitamini, interlökin-6 (IL-6, orta ve şiddetli hastalarda çalışıldı)] ve bilgisayarlı toraks tomografi (toraks BT) rutin olarak tüm hastalara başvuruları sırasında yapıldı ve sonuçları kayıt edildi. Tüm hastalarda nörolojik semptom ve bulgular başvuruları sırasında detaylı bir şekilde kayıt edildi. Gereklilik durumunda hastalara kranial BT yapıldı. Ancak bulaşı engellemek amacı ile kranial manyetik rezonans görüntüleme (MRG) genellikle tercih edilmedi.

\section{COVID-19 Şiddetine ve Nörolojik Semptomlara Göre Gruplar}

Hafif vakalarda, hafif klinik bulgular vardır, görüntüleme yöntemlerinde pnömoni bulgusu yoktur. Orta şiddetteki vakalarda ateş ve solunum yolu belirtileri ile birlikte görüntüleme yöntemlerinde pnömoni bulguları vardır. Şiddetli vakalar dinlenme sırasında solunum sayıs $\geq 30$ / dakika veya oksijen satürasyonu $\leq \% 93$ veya arteriyel parsiyel oksijen basinc1 (PaO2)/oksijen konsantrasyonu (FiO2) $\leq 300 \mathrm{mmHg}$ olan ve akciğer görüntülemelerinde 24-48 saat içinde >\%50 lezyon progresyonı görülen hastalardır. Kritik vakalar şok tablosunun, mekanik ventilasyon gerektirebilecek ciddi solunum yetmezliğinin veya yoğun bakım takibi gerektiren kombine diğer organ yetmezliklerinin gelişebildiği hastalardır (13).

Tüm hastalar COVID-19 şiddeti ile nörolojik semptom varlığına göre gruplara ayrıldı ve değişkenlere göre analizleri yapıldı. Çalışmaya yoğun bakım ünitesinde takip edilen kritik-ağır düzeydeki hastalar dahil edilmedi. Çalışmada şiddetli hasta sayısı yetersiz olduğundan, anlamlı istatistiksel veriler sağlamak amacı ile hastalık şiddeti grupları ikiye ayrıldı, İlk gruba hafif hastalığı (toraks BT bulgusu olmayan) olanlar, ikinci gruba ise orta ya da şiddetli hastalığı (torkas BT bulgusu olan) olanlar olarak dahil edildi.

\section{Istatistiksel analiz}

İstatistiksel analiz için SPSS 23.0 for Windows programı kullanıldı. Sürekli değişkenlerin normallik analizi Kolmogorov 
Smirnov testi ve beraberinde tanımlayıc istatistiklerden skewness ve kurtosis ile değerlendirildi. Tüm verilerde en az bir grupta veriler normal dağılmadığından tüm testler non-parametrik yapıldı. Tanımlayıcı istatistikler; kategorik değişkenler için sayı ve yüzde, sayısal değişkenler için ortanca (minumum-maksimum) olarak verildi. Bağımsız iki grupta sayısal değişkenlerin fark analizi Mann Whitney-U testi ile yapıldı. Bağımsız gruplarda oranların karşılaştırılması Ki-Kare Analizi ile yapıldı. İstatistiksel alfa anlamlılık seviyesi $\mathrm{p}<0,05$ olarak kabul edildi.

\section{Bulgular}

\section{Demografik Özellikler}

Bu çalışmaya kesin COVID-19 tanısı alarak hospitalize edilen ve çalışma kriterlerini karşılayan 66 hasta dahil edilmiştir. Hastaların yaş ortancası 34,5 (18-83) olup 33'ü kadın (\%50) ve 33'ü erkekti (\%50). Başvuru sırasında en sık görülen semptomları halsizlik-yorgunluk $(\% 54,5)$, ateş $(\% 48,5)$ ve öksürüktü $(\% 45,5) .19$ hastada $(\% 28,8)$ en az bir ko-morbid hastalık tespit edildi. Kronik nörolojik hastalık toplam 2 vakada (\%3) mevcuttu. En sik görülen ko-morbid hastalıklar hipertansiyon (HT) $(\% 16,7)$ ve diyabetes mellitus (DM) $(\% 13,6)$ idi. Hastaların hastanede kalış ortanca süresi 6 (1-26 gün) gündü (Tablo 1).

\section{Hasta Grupları ve Değişkenlerin Gruplar ile ilişkisi}

Toraks BT bulgusu 33 hastada (\%50) olmaylp 33 hastada (\%50) mevcuttu. Toraks BT bulgusu olan hastaların yaş ortancası [42 (21-71)], olmayanlara [27 (18-83)] göre anlamlı derecede yüksekti $(\mathrm{p}=0.015)$. Hastalık şiddeti (Toraks BT'de bulgu varlığı) ile cinsiyet arasında anlamlı bir ilişki saptanmadı $(\mathrm{p}=0.806)$. Solunum sıkıntısı beklenildiği üzere Toraks BT bulgusu olanlarda daha fazlaydı $(\mathrm{p}=0.024)$. Toraks BT bulgusu olanlarda ko-morbid hastalık daha çok görülse de fark anlamlı değildi ( $\mathrm{p}=0.057$ ). Sigara ve alkol kullanımı ile hastalık şiddeti arasında anlamlı ilişki saptanmadı. Toraks BT bulgusu olan hastaların serviste kalış süresi daha uzundu ( $\mathrm{p}=0.036)$ (Tablo 2).

43 hastada $(\% 65,2)$ en az bir nörolojik semptom gözlendi. 29 hastanın $(\% 43,9)$ başvurusu sırasında nörolojik semptom vardı. Nörolojik semptomu olan ve olmayan hastaların yaş ortancası ise sirasıyla 29 (18-71) ve 45 (18-83) idi $(\mathrm{p}=0.082)$. Nörolojik semptom varlığı ile cinsiyet arasında anlamlı bir ilişki saptanmadı $(\mathrm{p}=0.796)$. Ateş nörolojik semptomu olmayanlarda, olanlara göre anlamlı derecede yüksek bulundu ( $\mathrm{p}=0.047)$. İshal vakaların 7'sinde görüldü ve tümü nörolojik semptom gösterenlerde mevcuttu ( $\mathrm{p}=0.041)$. HT nörolojik semptomu olmayanlarda daha fazlayd $1(\mathrm{p}=0.028)$. Sigara ve alkol kullanımının nörolojik semptom varlığı ile ilişkisi yoktu (Tablo 2).

\section{Nörolojik Semptomlar}

En sık görülen nörolojik semptomlar hiposmi-anosmi (\%27,3), disguzi $(\% 27,3)$, baş ağrısı $(\% 25,8)$ ve kas ağrısı-kramptı
Tablo 1. COVID-19 Hastalarının Demografik Özellikleri

\begin{tabular}{|c|c|}
\hline & Total \\
\hline & Ortanca (min-max) / n (\%) \\
\hline Yaş & $34,5(18-83)$ \\
\hline \multicolumn{2}{|l|}{ Cinsiyet } \\
\hline Kadın & $33(\% 50)$ \\
\hline Erkek & $33(\% 50)$ \\
\hline \multicolumn{2}{|l|}{ Semptomlar } \\
\hline Ateş & $32(\% 48,5)$ \\
\hline Öksürük & $30(\% 45,5)$ \\
\hline Boğaz ağrısı & $14(\% 21,5)$ \\
\hline Göğüs ağrısı & $10(\% 15,4)$ \\
\hline Solunum sikıntıs1 & $8(\% 12,1)$ \\
\hline Sirt-bel ağrısı & $20(\% 30,3)$ \\
\hline Halsizlik-yorgunluk & $36(\% 54,5)$ \\
\hline İştah kaybı & $5(\% 7,6)$ \\
\hline İshal & $7(\% 10,6)$ \\
\hline Bulantı-kusma & $8(\% 12,1)$ \\
\hline Cilt döküntüsü & $4(\% 6,1)$ \\
\hline Karın ağrısı & $2(\% 3)$ \\
\hline Kronik nörolojik hastalık & $2(\% 3)$ \\
\hline Komorbid hastalık & $19(\% 28,8)$ \\
\hline HT & $11(\% 16,7)$ \\
\hline DM & $9(\% 13,6)$ \\
\hline Koroner arter hastalığ 1 & $1(\% 1,5)$ \\
\hline Obezite & - \\
\hline KOAH & $2(\% 3)$ \\
\hline Astım & $5(\% 7,6)$ \\
\hline İnme & $1(\% 1,5)$ \\
\hline Kanser & $1(\% 1,5)$ \\
\hline Bağışıklık sistemi hastalığı & $1(\% 1,5)$ \\
\hline Tiroit hastalığg & $1(\% 1,5)$ \\
\hline Epilepsi & $2(\% 3)$ \\
\hline KBY & - \\
\hline Sigara & $18(\% 27,3)$ \\
\hline Alkol & $6(\% 9,1)$ \\
\hline Serviste yatış süresi (gün) & $6(1-26)$ \\
\hline
\end{tabular}

$(\% 24,2)$. Bilinç bozukluğu 4 hastada $(\% 6,1)$ saptandı. İnme, ataksi ve epileptik nöbet hiçbir hastada gözlenmedi. Nörolojik semptomların hiçbiri hastalık şiddeti ile ilişkili bulunmadı (Tablo 3).

\section{Laboratuvar Bulguları}

Nörolojik semptomu olan hastalarda D-dimer, AST ve üre düzeyleri daha düşüktü (sırasıly $\mathrm{p}=0.003, \mathrm{p}=0.017, \mathrm{p}=0.047$ ). 
Tablo 2. Çalışma Gruplarına Göre COVID-19 Hastaları

\begin{tabular}{|c|c|c|c|c|c|c|}
\hline & \multicolumn{2}{|c|}{ Toraks BT bulgusu } & \multirow[b]{2}{*}{$\mathbf{p}$} & \multicolumn{2}{|c|}{ Nörolojik semptom } & \multirow[b]{2}{*}{$\mathbf{p}$} \\
\hline & Var & Yok & & Var & Yok & \\
\hline & \multicolumn{6}{|c|}{ ortanca (min-max) / n(\%) } \\
\hline Yaş & $42(21-71)$ & $27(18-83)$ & 0,015 & $29(18-71)$ & $45(18-83)$ & 0,082 \\
\hline Kadın & $17(\% 51,5)$ & $16(\% 48,5)$ & \multirow[t]{2}{*}{0,806} & $22(\% 51,2)$ & $11(\% 47,8)$ & \multirow[t]{2}{*}{0,796} \\
\hline Erkek & $16(\% 48,5)$ & $17(\% 51,5)$ & & $21(\% 48,8)$ & $12(\% 52,2)$ & \\
\hline \multicolumn{7}{|l|}{ Semptomlar } \\
\hline Öksürük & $16(\% 48,5)$ & $14(\% 42,4)$ & 0,621 & $17(\% 39,5)$ & $13(\% 56,5)$ & 0,187 \\
\hline Boğaz ağrısı & $9(\% 28,1)$ & $5(\% 15,2)$ & 0,203 & $10(\% 23,8)$ & $4(\% 17,4)$ & 0,547 \\
\hline Göğüs ağrısı & $6(\% 18,8)$ & $4(\% 12,1)$ & 0,459 & $8(\% 19)$ & $2(\% 8,7)$ & 0,269 \\
\hline Solunum sıkıntısı & $7(\% 21,2)$ & $1(\% 3)$ & 0,024 & $6(\% 14)$ & $2(\% 8,7)$ & 0,533 \\
\hline Sirt-bel ağrısı & $11(\% 33,3)$ & $9(\% 27,3)$ & 0,592 & $16(\% 37,2)$ & $4(\% 17,4)$ & 0,095 \\
\hline Halsizlik-yorgunluk & $20(\% 60,6)$ & $16(\% 48,5)$ & 0,323 & $25(\% 58,1)$ & $11(\% 47,8)$ & 0,423 \\
\hline Karın ağrısı & $1(\% 3)$ & $1(\% 3)$ & 1,000 & $2(\% 4,7)$ & - & 0,294 \\
\hline Kronik nörolojik hastalık & $1(\% 3)$ & $1(\% 3)$ & 1,000 & $2(\% 4,7)$ & - & 0,294 \\
\hline Komorbid hastalık & $13(\% 39,4)$ & $6(\% 18,2)$ & 0,057 & $10(\% 23,3)$ & $9(\% 39,1)$ & 0,175 \\
\hline HT & $8(\% 24,2)$ & $3(\% 9,1)$ & 0,099 & $4(\% 9,3)$ & $7(\% 30,4)$ & 0,028 \\
\hline $\mathrm{DM}$ & $5(\% 15,2)$ & $4(\% 12,1)$ & 0,720 & $4(\% 9,3)$ & $5(\% 21,7)$ & 0,161 \\
\hline Koroner arter hastalığ & - & $1(\% 3)$ & 0,314 & - & $1(\% 4,3)$ & 0,168 \\
\hline Obezite & - & - & - & - & - & - \\
\hline KOAH & $1(\% 3)$ & $1(\% 3)$ & 1,000 & $1(\% 2,3)$ & $1(\% 4,3)$ & 0,648 \\
\hline Astım & $2(\% 6,1)$ & $3(\% 9,1)$ & 0,642 & $5(\% 11,6)$ & - & 0,089 \\
\hline İnme & $1(\% 3)$ & - & 0,314 & $1(\% 2,3)$ & - & 0,461 \\
\hline Kanser & - & $1(\% 3)$ & 0,314 & - & $1(\% 4,3)$ & 0,168 \\
\hline
\end{tabular}

Mann Whiney-U test, Ki-kare testi

Tablo 3. COVID-19 Hastalarının Nörolojik Semptomları

\begin{tabular}{|c|c|c|c|c|}
\hline & \multirow[t]{2}{*}{ Total } & \multicolumn{2}{|c|}{ Toraks BT bulgusu } & \multirow[t]{2}{*}{$\mathbf{p}$} \\
\hline & & Var & Yok & \\
\hline & \multicolumn{3}{|c|}{ ortanca $(\min -m a x) / n(\%)$} & \\
\hline \multicolumn{5}{|l|}{ Semptomlar } \\
\hline Hiposmi-anosmi & $18(\% 27,3)$ & $10(\% 30,3)$ & $8(\% 24,2)$ & 0,580 \\
\hline Disguzi & $18(\% 27,3)$ & $10(\% 30,3)$ & $8(\% 24,2)$ & 0,580 \\
\hline Görme bozukluğu & $1(\% 1,5)$ & $1(\% 3)$ & - & 0,314 \\
\hline Kas ağrisı & $16(\% 24,2)$ & $10(\% 30,3)$ & $6(\% 18,2)$ & 0,251 \\
\hline Nöropatik ağrı-nöropati & $2(\% 3)$ & $2(\% 6,1)$ & - & 0,151 \\
\hline İnme & - & - & - & - \\
\hline Baş ağrısı & $17(\% 25,8)$ & $9(\% 27,3)$ & $8(\% 24,2)$ & 0,778 \\
\hline Dizziness & $5(\% 7,6)$ & $3(\% 9,1)$ & $2(\% 6,1)$ & 0,642 \\
\hline Baş dönmesi & $5(\% 7,6)$ & $4(\% 12,1)$ & $1(\% 3)$ & 0,163 \\
\hline Ataksi & - & - & - & - \\
\hline Bilinç bozukluğu & $4(\% 6,1)$ & $2(\% 6,1)$ & $2(\% 6,1)$ & 1,000 \\
\hline Ajitasyon & $1(\% 1,5)$ & $1(\% 3)$ & - & 0,314 \\
\hline Nöbet geçirme-kasılma & - & - & - & - \\
\hline Menenjit-ensefalit & - & - & - & - \\
\hline
\end{tabular}

Hemoglobin $(\mathrm{Hb})$ ise daha yüksekti $(\mathrm{p}=0.039)$. IL-6 düzeyleri nörolojik semptomu olan hastalarda daha yüksek düzeyde olmasına rağmen fark anlamlı değildi $(\mathrm{p}=0.142)$. Hastalık şiddeti ile laboratuvar değerlerinin hiçbiri arasında anlamlı bir ilişki saptanmadı (Tablo 4).

\section{COVID-19 Şiddeti ile Nörolojik Semptom Varlığının ilişsisi}

33 hasta $(\% 50)$ hafif, 28 hasta $(\% 42,4)$ orta ve 5 hasta $(\% 7,6)$ şiddetli COVID-19 hastası olarak değerlendirildi. Nörolojik semptomu olan hastaları \%58,1'inde toraks BT bulgusu varken, nörolojik semptomu olmayanlarda ise bu oran $\% 34,8$ 'di ancak anlamlı fark saptanmad $1(\mathrm{p}=0.071$ ) (Tablo 5). Toraks BT bulgusu olmayan grupta nörolojik semptomu olanların serviste kalış süresi olmayanlara göre daha uzundu $(\mathrm{p}=0.017)$. Nörolojik bulgusu olmayan grupta, toraks BT bulgusu olanların, serviste kalış süresi olmayanlara göre daha uzundu ( $\mathrm{p}=0.009)$ (Tablo 6). 
Tablo 4. COVID-19 Hastalarının Laboratuvar Bulguları

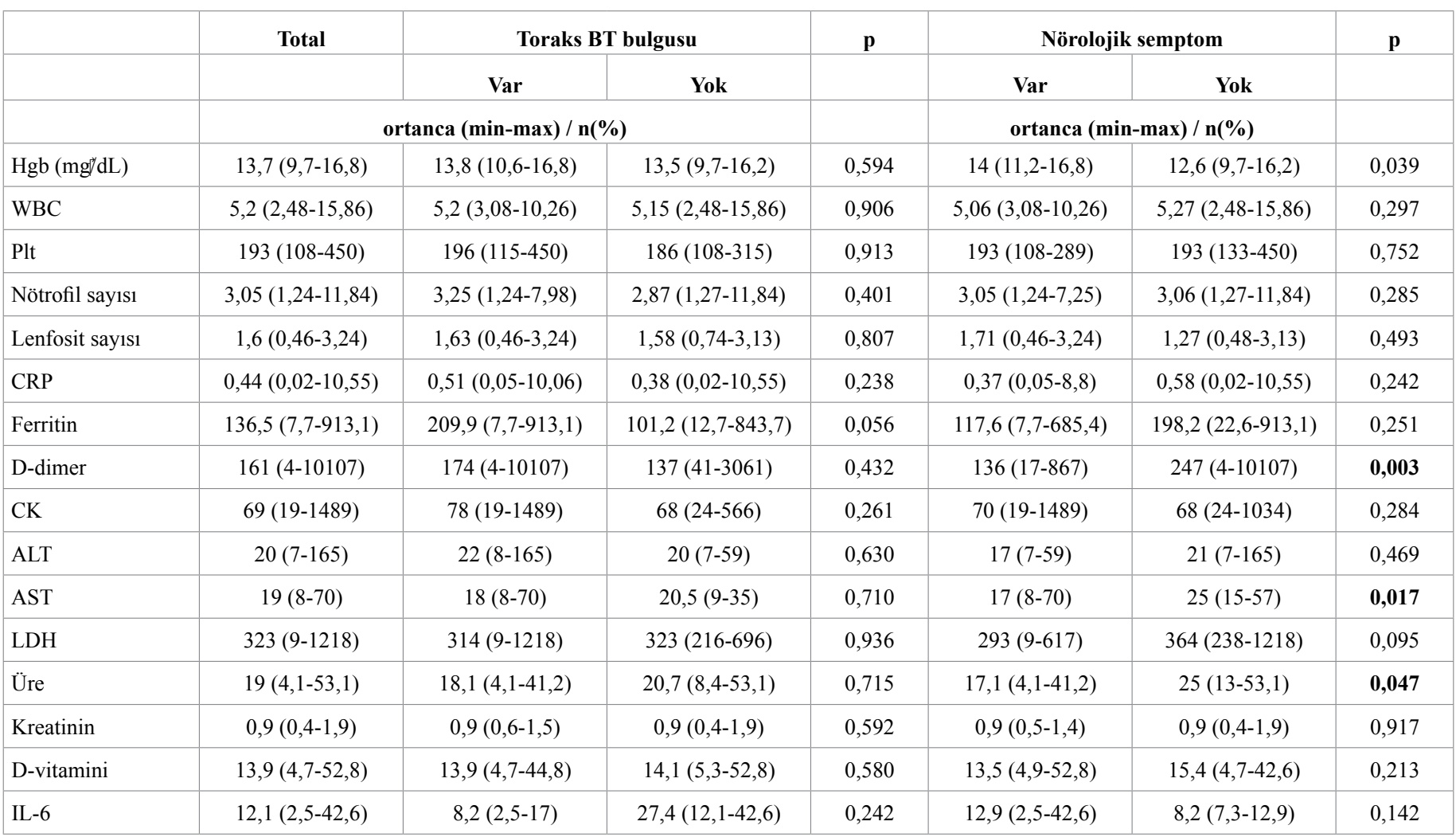

Mann Whiney-U test, Ki-kare testi

Tablo 5. COVID-19 Şiddeti ve Nörolojik Semptom Varlığı ile İlişkisi

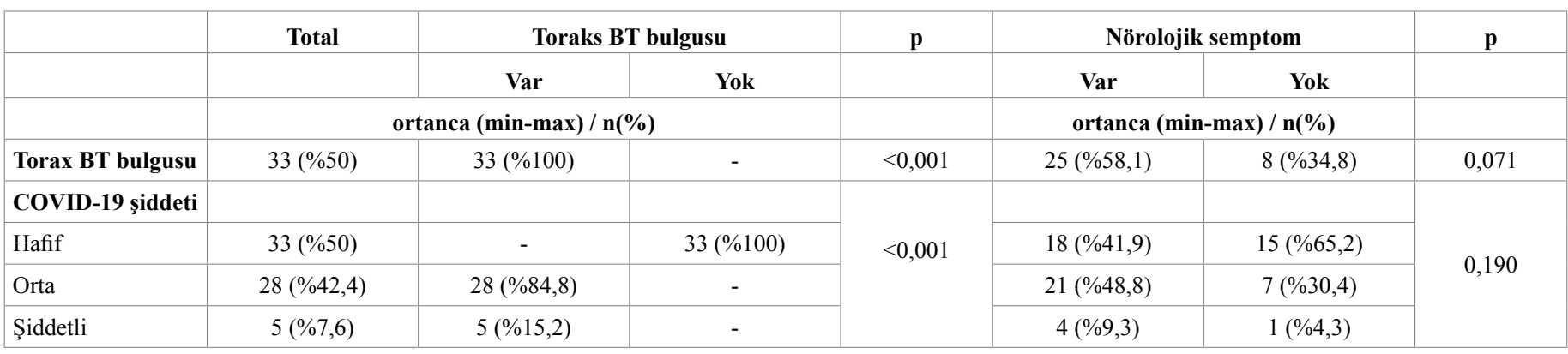

Mann Whiney-U test, Ki-kare testi

Tablo 6. COVID-19 Hastalarının Hastanede Yatış Süreleri

\begin{tabular}{|c|c|c|c|c|c|c|}
\hline & \multicolumn{2}{|c|}{ Toraks BT bulgusu var } & $\mathbf{p}$ & \multicolumn{2}{|c|}{ Toraks BT bulgusu yok } & $\mathbf{p}$ \\
\hline & \multicolumn{2}{|c|}{ Nörolojik semptom } & & \multicolumn{2}{|c|}{ Nörolojik semptom } & \\
\hline & Var & Yok & & Var & Yok & \\
\hline & \multicolumn{2}{|c|}{ ortanca (min-max) } & & \multicolumn{2}{|c|}{ ortanca (min-max) } & \\
\hline \multirow[t]{5}{*}{ Serviste yatış süresi (gün) } & $7(2-26)$ & $7,5(5-14)$ & 0,476 & $7(2-14)$ & $5(1-21)$ & $\mathbf{0 , 0 1 7}$ \\
\hline & \multicolumn{2}{|c|}{ Nörolojik semptom var } & $\mathrm{p}$ & \multicolumn{2}{|c|}{ Nörolojik semptom yok } & $\mathrm{p}$ \\
\hline & \multicolumn{2}{|c|}{ Toraks BT bulgusu } & & \multicolumn{2}{|c|}{ Toraks BT bulgusu } & \\
\hline & Var & Yok & & Var & Yok & \\
\hline & \multicolumn{2}{|c|}{ ortanca (min-max) } & & \multicolumn{2}{|c|}{ ortanca (min-max) } & \\
\hline Serviste yatış süresi (gün) & $7(2-26)$ & $7(2-14)$ & 0,940 & $7,5(5-14)$ & $5(1-21)$ & 0,009 \\
\hline \multicolumn{7}{|l|}{ Mann Whiney-U test } \\
\hline
\end{tabular}




\section{Tartışma}

Hastanede COVID-19 tanısı ile yatan hastalardaki nörolojik semptomların analiz edildiği bu çalışmada, COVID-19 hastalarının \%65,2'sinde en az bir nörolojik semptom tespit edilmiştir. Mevcut pandemi sürecinde gerçekleştirilen çalışmalarda COVID-19'lu hastalarda farklı oranlarda nörolojik semptomlar gözlenmiştir. Mao ve ark. (14) COVID-19 hastalarının \%36,4'ünde, Romero-Sanches ve ark. (15) \%57,4'ünde. Karadaş ve ark. (16) \%34,7'sinde nörolojik semptom saptamışlardır. Bazı çalışmalarda COVID-19 şiddeti ile nörolojik semptom ilişkisi bildirilmiştir $(14,16)$. Çalışmamızda da nörolojik semptomu olan hastalarda, hastalık şiddeti daha yüksek olmasına rağmen bu fark istatistiksel anlamlı değildi $(\mathrm{p}=0,071)$. Buna rağmen hafif şiddetli COVID19'da nörolojik semptomu olan hastaların hastanede yatış süreleri daha uzundu.

Genomik özelliklerine göre SARS-CoV-2, “Orta Doğu Solunum Sendromu koronavirüsü" (MERS-CoV) ve "şiddetli akut solunum yolu sendromu koronavirüsü” (SARS-CoV) gibi beta-korona virüs ailesinin üyesidir ve SARS-CoV ile benzer antijenik özellik gösterir (17-19). Nörolojik tutulum SARSCoV ve MERS-CoV'da da gösterilmiştir. Hatta SARS-CoV'un nükleik asidi enfekte hastaların beyin omurilik sıvılarında (BOS) ve otopsi sırasında beyinlerinde de gösterilmiştir (14). ACE-2, SARS-CoV-2'nin spike proteini için hedef reseptördür. Solunum sistemi epiteli, akciğer parankimi, vasküler endotel, böbrek hücreleri, ince barsak, testis ve beyin virüsün ana hedef organlarıdır. Ayrıca ACE-2 nöronlar dışında glial hücrelerde de eksprese edilmektedir. Nöron ve glial hücrelerin enfekte olması sonucunda da SARS-CoV-2 santral sinir sistemine (SSS) yayılabilir. Bunun yanında yakın zamanlı çalışmalar SARSCoV-2'nin alt solunum yollarından, mekano ve kemoreseptörler aracılığı ile sinaptik yollar sonucunda bulbusa yayılabildiğini ve beyin sapının, beyinde en çok etkilenen bölge olabileceğini bildirmiştir $(20,21, \mathbf{2 2})$.

COVID-19'un sinir sistemi bulgularına yol açma mekanizmaları: 1. Pulmoner hastalık, Sistemik İnflamatuar Yanıt Sendromu (SIRS), sepsis ya da çoklu organ yetmezliği sonucu immün aracılı hasarlanma, 2. Virüsün SSS'yi direkt invazyonu (olfaktör sinir başta olmak üzere periferik sinirler aracılığı ile retrograd aksonal transport, transsinaptik yol ve hematojen yol), 3 . Hipoksik hasarlanma, 4. Hiperkoagülabilite ile ilişkili trombotik komplikasyonlar, 5. Enfekte monosit ve makrofajların kan beyin bariyerinde (KBB) endotelyal hasar yaparak SSS'ye geçişi şeklindedir $(17,21,22,23)$.

Çalışmamızda, en sık görülen nörolojik semptomlar hiposmianosmi, disguzi, baş ağrısı ve kas ağrısı idi. Mao ve ark. (14) dizziness, baş ağrısı, kas tutulumunu; Karadaş ve ark. (16) ise baş ağrısı ve kas ağrısını en sık görülen nörolojik semptomlar olarak bildirmişlerdir. Tat ve koku bozukluğunu ise çalışmamıza kıyasla düşük oranda bulmuşlardır. Yakın zamanlı çalışmalarda genç, hafif ve orta şiddetli COVID-19'lu hastalarda, olfaktör ve gustatuar disfonksiyon oldukça yüksek oranda bildirilmiş̧ir. Olfaktör epitelin SARS-CoV-2 replikasyonu için önemli bir bölge olduğu düşünülmektedir (24). Çalışmamızda yer alan hastaların çok büyük bir bölümünün hafif ve orta şiddette hastalığa sahip olması, diğer çalışmalara göre daha genç yaşlarda olmaları ve nörolojik semptom gösteren hastaların, göstermeyenlere göre neden daha genç yaşta olması, bu farkın sebebi olabilir.

$\mathrm{Bu}$ çalışmada, nörolojik semptomların çoğu, hastaların başvuruları sırasında mevcuttu. Benzer şekilde Mao ve ark. (14) ile Romero-Sanches ve ark. (15) da nörolojik semptomların çoğunu COVID-19'un erken döneminde gözlemişlerdir. Çeşitli çalışmalarda ise nörolojik semptomla başvuru sıklığ farklı oranlarda bulunmuştur. Bunun sebebi ACE-2 reseptör polimorfizmi ve SARS-CoV-2 strain varyasyonu gibi genetik faktörlere dayanıyor olabilir (21).

Çalışmamızın bir diğer sonucu olarak istatistiksel anlam çıkmasa da IL-6 düzeyini nörolojik semptomu olan hastalarda daha yüksek gözlemledik. SARS-CoV-2'nin oluşturduğu sistemik inflamatuar yanıtın KBB'yi yıkarak, periferal sitokinlerin SSS'ye geçişine neden olduğu ve ortaya çıkan indirekt nöroinflamatuar reaksiyonun COVID-19'daki nörolojik semptomlara sebep olabildiği düşünülmektedir (15).

Bu çalışmanın bazı kısıtlılıkları vardı. Çalışmanın tek merkezde düzenlenmiş olması ve hasta sayısının göreceli az olması sonuçlardan nedensel çıkarım yapılmasını güçleştiriyor olabilir. Şiddeti ve ileri yaş hasta grubunun yetersiz olması ile kritik hasta grubunun çalışmaya dahil edilmemesi, COVID-19 şiddeti ile şiddetli nörolojik semptomların arasında ilişki olup olmadığ konusunda çıkarımda bulunmamıza engel oldu. Son olarak bulaşı önlemek amacı ile hastaların büyük kısmına kranial MRG, elektroensefalografi (EEG), elektromiyografi (EMG) ve sinir ileti çalışmaları ile lomber ponksiyon (LP) gibi tanı yöntemlerinin uygulanamaması, bazı nörolojik semptomların teyit edilmesini önlemiş olabilir.

\section{Sonuç}

SARS-CoV-2'nin nöroinvaziv ve nörotropik özelliklerinin olduğu bilinmektedir ve COVID-19 surasinda sinir sisteminin direkt ya da sitokin salınımına bağlı indirekt hasarlanması sonucu birçok nörolojik semptom görülebilmektedir. $\mathrm{Bu}$ çalışmada nörolojik semptomu olan COVID-19 hastalarının daha genç yaşta olduğu gözlendi. Ayrıca koku, tat bozukluğu ve baş ağrısı gibi müphem nörolojik semptomlarla başvuran hastaların genç yaş grubunda olduğu ve hafif hastalıkta daha çok gözlendiği saptandı. $\mathrm{Bu}$ nedenle pandemi döneminde nörolojik semptomlarla başvuran hastalarda, tanı gecikmesini ve enfeksiyonun yayılmasını engellemek için COVID-19 mutlaka ayırıcı tanılar arasında bulundurulmalıdır. 
Etik Kurul Onayı: Bu çalışma İyi Klinik Uygulama ilkelerine ve Helsinki Bildirgesi'ne uygun olarak düzenlenmiştir. Çalışma protokolü Yüksek İhtisas Üniversitesi Etik Kurulu tarafından onaylanmıştır.

Hakem Değerlendirmesi: Dış Bağımsız.

Bilgilendirilmiş Onam: Katılımcılardan bilgilendirilmiş gönüllü onam formu alınmıştır.

Çıkar Çatışması: Yazarın herhangi bir çıkar çatışması bulunmamaktadır.

Finansal Destek: Yoktur

Ethics Committee Approval: This study was organized in accordance with the principles of Good Clinical Practice and the Declaration of Helsinki. The study protocol was approved by the Yuksek Ihtisas University Ethics Committee.

Peer-review: Externally peer-reviewed

Informed consent: Informed consent form was obtained from the participants.

Conflict of Interest: The author do not have any conflicts of interest.

Financial Disclosure: None

\section{Kaynaklar}

1. Zhu N, Zhang D, Wang W, Li X, Yang B, Song J, et al.; China Novel Coronavirus Investigating and Research Team. A Novel Coronavirus from Patients with Pneumonia in China, 2019. N Engl J Med 2020;382(8):727-733.

2. Ge H, Wang X, Yuan X, Xiao G, Wang C, Deng T, et al. The epidemiology and clinical information about COVID-19. Eur J Clin Microbiol Infect Dis 2020;39(6):1011-1019.

3. Ahn DG, Shin HJ, Kim MH, Lee S, Kim HS, Myoung J, et al. Current Status of Epidemiology, Diagnosis, Therapeutics, and Vaccines for Novel Coronavirus Disease 2019 (COVID-19). J Microbiol Biotechnol 2020;30(3):313-324.

4. Shi Y, Wang G, Cai XP, Deng JW, Zheng L, Zhu HH, et al. An overview of COVID-19. J Zhejiang Univ Sci B 2020;21(5):343-360.

5. Wang Y, Wang Y, Chen Y, Qin Q. Unique epidemiological and clinical features of the emerging 2019 novel coronavirus pneumonia (COVID-19) implicate special control measures. J Med Virol 2020;92(6):568-576.

6. Coronaviridae Study Group of the International Committee on Taxonomy of Viruses. The species Severe acute respiratory syndrome-related coronavirus: classifying 2019-nCoV and naming it SARS-CoV-2. Nat Microbiol 2020;5(4):536-544.

7. Rothan HA, Byrareddy SN. The epidemiology and pathogenesis of coronavirus disease (COVID-19) outbreak. J Autoimmun 2020;109:102433. https://doi. org/10.1016/j.jaut.2020.102433. [E-pub 2020 Feb 26].

8. Vonck K, Garrez I, De Herdt V, Hemelsoet D, Laureys G, Raedt R, et al. Neurological manifestations and neuro-invasive mechanisms of the severe acute respiratory syndrome coronavirus type 2. Eur J Neurol 2020;27(8):15781587.
9. Yachou Y, El Idrissi A, Belapasov V, Ait Benali S. Neuroinvasion, neurotropic, and neuroinflammatory events of SARS-CoV-2: understanding the neurological manifestations in COVID-19 patients. Neurol Sci 2020;41(10):2657-2669.

10. Montalvan V, Lee J, Bueso T, De Toledo J, Rivas K. Neurological manifestations of COVID-19 and other coronavirus infections: A systematic review. Clin Neurol Neurosurg 2020;194:105921. https://doi.org/10.1016/j. clineuro.2020.105921. [Epub 2020 May 15].

11. World Health Organization. Clinical management of severe acute respiratory infection when Novel coronavirus (nCoV) infection is suspected: interim guidance, 13 March 2020. Erişim 27 Mart 2020.

12. Huang C, Wang Y, Li X, Ren L, Zhao J, Hu Y, et al. Clinical features of patients infected with 2019 novel coronavirus in Wuhan, China. Lancet 2020;395(10223):497-506.

13. Liang T (Ed.). Handbook of COVID-19 Prevention and Treatment. Zhejiang, China: Zhejiang University of Medicine, 2020.

14. Mao L, Jin H, Wang M, Hu Y, Chen S, He Q, et al. Neurologic Manifestations of Hospitalized Patients With Coronavirus Disease 2019 in Wuhan, China JAMA Neurol 2020;77(6):683-690.

15. Romero-Sánchez CM, Díaz-Maroto I, Fernández-Díaz E, Sánchez-Larsen Á, Layos-Romero A, García-García J, et al. Neurologic manifestations in hospitalized patients with COVID-19: The ALBACOVID registry. Neurology 2020;95(8):e1060-e1070.

16. Karadaş Ö, Öztürk B, Sonkaya AR. A prospective clinical study of detailed neurological manifestations in patients with COVID-19. Neurol Sci 2020;41(8):1991-1995.

17. Gençler OS. COVID-19: Nörolojik Semptom ve Bulgular. YIU Saglik Bil Derg 2020;1:31-35.

18. Guan WJ, Ni ZY, Hu Y, Liang WH, Ou CQ, He JX, et al.; China Medical Treatment Expert Group for Covid-19. Clinical Characteristics of Coronavirus Disease 2019 in China. N Engl J Med 2020;382(18):1708-1720.

19. Mahalakshmi AM, Ray B, Tuladhar S, Bhat A, Paneyala S, Patteswari D, et al. Does COVID-19 contribute to development of neurological disease? Immun Inflamm Dis 2021;9(1):48-58.

20. Li YC, Bai WZ, Hashikawa T. The neuroinvasive potential of SARS-CoV2 may play a role in the respiratory failure of COVID-19 patients. J Med Virol 2020;92(6):552-555.

21. Harapan BN, Yoo HJ. Neurological symptoms, manifestations, and complications associated with severe acute respiratory syndrome coronavirus 2 (SARS-CoV-2) and coronavirus disease 19 (COVID-19). J Neurol 2021;268(9):3059-3071

22. Sepehrinezhad A, Shahbazi A, Negah SS. COVID-19 virus may have neuroinvasive potential and cause neurological complications: a perspective review. J Neurovirol 2020;26(3):324-329.

23. Mainali S, Darsie M. Neurologic manifestations \& Associations of COVID-19. Practical neurology 2021. http://v2.practicalneurology.com/pdfs/PN0121_CF_ NeurologyCOVID19.pdf.

24. Orsucci D, Ienco EC, Nocita G, Napolitano A, Vista M. Neurological features of COVID-19 and their treatment: a review. Drugs Context 2020;9:2020-5-1. https://doi.org/10.7573/dic.2020-5-1. 